Majalah Kedokteran UKI 2020 Vol XXXVI No.2

Mei - Agustus

Artikel Asli

\title{
Profil Pasien Spondilitis Tuberkulosis (Pott's Disease) di Rumah Sakit Pusat Angkatan Darat Gatot Soebroto
}

\author{
Irfan Y. Mijaya,,${ }^{*}$ Chyntia M. Sahetapy, ${ }^{1}$ Dewiyana A.Kusmana ${ }^{2}$ \\ ${ }^{1}$ Departemen Ilmu Penyakit Saraf Fakultas Kedokteran Universitas Kristen Indonesia \\ ${ }^{2}$ Rumah Sakit Pusat Angkatan Darat Gatot Subroto, Jakarta
}

\begin{abstract}
Abstrak
Spondilitis tuberkulosis (TB) atau Pott's disease adalah infeksi tulang belakang yang disebabkan Mycobacterium tuberculosis akibat TB ekstrapulmoner. Penyakit ini tergantung berbagai faktor seperti usia, status gizi, dan penyakit penyerta. Penelitian deskriptif ini dilakuakn untuk mengetahui Profil pasien spondilitis tuberkulosis di Rumah Sakit Pusat Angkatan Darat (RSPAD) Gatot Soebroto. Data diperoleh dari rekam medis sebanyak 75 sampel. Penelitian ini menunjukkan jenis kelamin laki - laki (50,7\%), kelompok usia $21-29$ tahun $(29,3 \%)$, dan status gizi normal $(33,3 \%)$ merupakan kelompok yang terbanyak terkena spondilitis tuberkulosis (TB). Jenis pekerjaan terbanyak merupakan ibu rumah tangga $(28,0 \%)$. Sebanyak 69 pasien $(92 \%)$ tidak memiliki riwayat merokok dan semua pasien tidak memiliki riwayat mengonsumsi alkohol. Hanya 1 orang pasien spondilitis TB yang memiliki hasil basil tahan asam (BTA) positif. Sebanyak 41 orang $(54,7 \%)$ pasien spondilitis TB didiagnosis melalui Magnetic Resonance Imaging/ Computerized Tomographic Scan (MRI/CT SCAN) dengan lesi spondilitis TB terbanyak terdapat pada torakal. Kemampuan MRI mendiagnosis lebih baik dibandingkan PCR dan BTA.
\end{abstract}

Kata kunci: Status Gizi, Torakal, Basil Tahan Asam

\section{The Profile of Tuberculosis Spondylitis patients (Pott's Disease) at Rumah Sakit Pusat Angkatan Darat Gatot Soebroto}

\begin{abstract}
Tuberculous spondylitis (TB) or Pott's disease is a spinal infection caused by Mycobacterium tuberculosis due to extrapulmonary TB. This disease depends on various factors such as age, nutritional status, and comorbidities. This descriptive study was conducted to determine the profile of tuberculosis spondylitis patients at the Gatot Soebroto Central Army Hospital (RSPAD). Data obtained from medical records of 75 samples. This study showed that male gender (50.7\%), age group 21-29 years (29.3\%), and normal nutritional status (33.3\%) were the groups most affected by tuberculosis spondylitis (TB). Most types of work were housewives (28.0\%). A total of 69 patients (92\%) had no history of smoking and all patients had no history of consuming alcohol. Only 1 TB spondylitis patient had positive acid-resistant bacilli (AFB). A total of 41 people (54.7\%) TB spondylitis patients were diagnosed through Magnetic Resonance Imaging / Computerized Tomographic Scan (MRI / CT $S C A N)$ with the most TB spondylitis lesions found in the thoracic. The ability of MRI to diagnose is better than $P C R$ and BTA.
\end{abstract}

Key words: Nutritional Status, Thoracic, Acid Resistant Basil

*IYM: Penulis Koresponden; E-mail: irfan.mijaya11@gmail.com

Makalah ini merupakan preprint dan belum selesai menjalani proses review dan editing

\section{Pendahuluan}

Spondilitis tuberkulosis (TB) atau dikenal dengan Pott's disease adalah penyakit infeksi yang disebabkan oleh kuman Mycobacterium tuberculosis yang mengenai tulang belakang. ${ }^{1}$ Sekitar 20\% infeksi TB paru akan menyebar keluar paru (TB ekstrapulmoner). Sekitar 
10\%dari TB ekstrapulmoner merupakan TB osteoartikular, dan sekitar setengah dari pasien memiliki infeksi TB tulangbelakang. ${ }^{2}$

Menurut Faried et al, ${ }^{3}$ tulang belakang adalah daerah yang paling sering terlibat, yaitu $50 \%$ dari seluruh kasus tuberkulosis tulang, 15\% dari kasus tuberkulosis ekstrapulmonal dan 3-5\% dari seluruh kasus tuberkulosis.

Faktor pertahanan tubuh pasien terhadap infeksi tuberkulosis tergantung dari usia, jenis kelamin, nutrisi, faktor toksik dan penyakit penyerta. Pada bayi sampai dengan usia dua tahun, infeksi dapat terjadi dalam bentuk berat secara hematogen. Setelah pubertas daya tahan tubuh meningkat tetapi tetap dapat terjadi infeksi di paru-paru. Puncak angka kejadian infeksi yaitu pada kelompok usia 40-50 untuk perempuan dan 60 tahun untuk laki-laki. Kondisi malnutrisi, riwayat kebiasaan merokok dan konsumsi alkohol menyebabkan penurunan daya tahan tubuh, serta penyakit penyerta seperti infeksi HIV dan diabetes mellitus juga meningkatkan resiko terinfeksi tuberkulosis. ${ }^{1}$

Tujuan penelitian ini untuk mengetahui karakteristik kelompok usia, jenis kelamin, status gizi, jenis pekerjaan, faktor toksik, riwayat konsumsi OAT, hasil pemeriksaan BTA, pemeriksaan mikrobiologi lainnya serta hasil pemeriksaan radiologis penderita spondilitis tuberkulosis di RSPAD Gatot Subroto periode 2017-2019.

\section{Bahan dan Cara}

Penelitian ini bersifat deskriptif, menggunakan data rekam medik pasien terdiagnosis spondilitis tuberkulosis di RSPAD Gatot Soebroto periode Januari 2017 - Desember 2019. Penelitian ini telah disetujui oleh direktur RSPAD Gatot Soebroto dengan nomor surat B/2456/VIII/2020.

Subyek penelitian adalah pasien yang telah didiagnosis sebagai spondilitis tuberkulosis. Didapat sebanyak 75 subyek yang berasal dari periode Januari 2017 - Desember2019. Data yang dikumpulkan meliputi data demografis, status gizi, jenis kekerjaan, kebiasaan merokok, konsumsi alkohol, riwayat konsumsi OAT, hasil pemeriksaan BTA, pemeriksaan mikrobiologi lainnya serta hasil pemeriksaan radiologis

\section{Hasil}

Sejak bulan Januari 2017 - Desember 2019, didapatkan 75 rekam medik pasien yang memiliki data lengkap. Data demografis pasien disajikan pada Tabel 1.

Tabel 1. Data Demografis Pasien Penderita Spondilitis Tuberkulosis

\begin{tabular}{lcc}
\hline Variabel & $\mathbf{n}(\mathbf{7 5 )}$ & $\mathbf{\%}$ \\
\hline Jenis Kelamin & & \\
Laki-laki & 38 & 50,7 \\
Perempuan & 37 & 49,3 \\
Usia & & \\
$1-4$ tahun & 1 & 1,3 \\
$5-14$ tahun & 2 & 2,7 \\
$15-24$ tahun & 18 & 24 \\
$25-34$ tahun & 14 & 18,7 \\
$35-44$ tahun & 16 & 21,3 \\
$45-54$ tahun & 14 & 18,7 \\
$55-64$ tahun & 7 & 9,3 \\
$65-74$ tahun & 3 & 4 \\
\hline
\end{tabular}


Pada penelitian ini ditemukan 38 orang laki-laki menderita spondilitis tuberkulosis dan sisanya perempuan. Spondilitis tuberkulosis paling banyak ditemukan pada kelompok usia15 - 24 tahun (24\%) diikuti kelompok umur 35 - 45 tahun $(21,3 \%)$ dan yang paling sedikit adalah kelompok usia 1 - 4 tahun (1,3\%). Usia termuda adalah 3 tahun dan usia tertua yaitu 69 tahun (Tabel 1).

Tabel 2. Status Gizi Berdasarkan Indeks Massa Tubuh (IMT), Jenis Pekerjaan, Kebiasaan Merokok dan Konsumsi Alkohol

\begin{tabular}{lcc}
\hline Variabel & n (75) & \% \\
Status Gizi & & \\
Gemuk & 10 & 13,3 \\
Kurus & 22 & 29,3 \\
Normal & 25 & 33,3 \\
Obesitas I & 14 & 18,7 \\
Obesitas II & 4 & 5,3 \\
Jenis Pekerjaan & & \\
Tidak Bekerja & 12 & 16,0 \\
PNS/TNI/Polri/BUMN/BUMD & 7 & 9,3 \\
Wiraswasta & 9 & 12,0 \\
Lain-lain & 24 & 32,0 \\
Pegawai Swasta & 19 & 25,3 \\
Pelajar & 4 & 5,3 \\
Riwayat Merokok & & \\
Ya & 6 & 8,0 \\
Tidak & 69 & 92,0 \\
Riwayat Konsumsi Alkohol & & \\
Tidak & 75 & 100 \\
\hline
\end{tabular}

Kelompok IMT terbanyak pada kasus spondilitis TB di RSPAD Gatot Soebroto adalah pada kelompok Normal sebanyak 25 orang $(33,3 \%)$, dan yang paling sedikit adalah kelompok obesitas II sebanyak 4 orang $(5,3 \%)$.

Jenis pekerjaan terbanyak yang terdiagnosis spondilitis TB adalah lain-lain sebanyak 24 orang $(32,0 \%)$ dan yang paling sedikit adalah pelajar sebanyak 4 orang $(5,3 \%)$.

Pasien dengan riwayat tidak merokok didapatkan sebanyak 69 orang (92\%) dan yang tidak mempunyai riwayat merokok 6 orang $(8,0 \%)$.

Tabel 3. Karakteristik Berdasarkan Riwayat Konsumsi OAT, Tes BTA, Pemeriksaan Mikrobiologis Lainnya

\begin{tabular}{lcc}
\hline Variabel & N (75) & \% \\
\hline Riwayat Konsumsi OAT & 27 & 36,0 \\
Ya & 48 & 64,0 \\
Tidak & & \\
Hasil Tes BTA (n=26) & 1 & 3,9 \\
Positif & 25 & 96,1 \\
Negatif & 5 & 71,4 \\
Pemeriksaan Mikrobiologis Lainnya (n=7) & 1 & 14,3 \\
Polymerase Chain Reaction-TB & 1 & 14,3 \\
Enzyme-Linked Immunosorbent Assay & & \\
Histopatologi & 41 & 82,0 \\
Jenis Pemeriksaan Radiologi (n=50) &
\end{tabular}


Pasienyang tidak pernah mengonsumsi OAT didapatkan 48 orang (64\%) dan pasien mengonsumsi OAT sebanyak 27 orang (36\%).

Didapatkan pasien dengan hasil BTA negatif 25 orang $(96,1 \%)$ dan hanya satu orang $(3,9 \%)$ dengan hasil BTA positif.

Pasien dengan data positif PCR TB didapatkan sebanyak 5 orang $(71,4 \%)$ diikuti pasien dengan data positif ELISA 1 orang (14,3\%) dan pasien dengan data positif Histopatologi 1 orang $(14,3 \%)$. Pada tabel didapatkan hasil terbanyak pada pasien yang diperiksa dengan MRI/CT SCAN sebanyak 41 orang $(82,0 \%)$ diikuti pasien yang diperiksa dengan pemeriksaan radiologis regio toraks 9 orang $(18,0 \%)$.

\section{Tabel 4. Karakteristik Berdasarkan Lokasi Lesi, Abses Paravertebral, Degenerasi Diskus dan Fraktur Kompresi.}

\begin{tabular}{lcc}
\hline Variabel & N $\mathbf{( 7 5 )}$ & $\mathbf{\%}$ \\
\hline Lokasi Lesi berdasarkan Regio $(\mathbf{n = 5 0})$ & 1 & 2 \\
Servikal & 20 & 40 \\
Torakal & 12 & 24 \\
Lumbal & 10 & 20 \\
Torakolumbal & 7 & 14 \\
Lumbosakral & & \\
Lokasi Lesi berdasarkan Regio (n=50) & 1 & 0,58 \\
C3 & 1 & 0,58 \\
C4 & 1 & 0,58 \\
C5 & 1 & 0,58 \\
T1 & 3 & 1,74 \\
T2 & 5 & 2,90 \\
T3 & 8 & 4,65 \\
T4 & 10 & 5,81 \\
T5 & 9 & 5,23 \\
T6 & 9 & 5,23 \\
T7 & 10 & 5,81 \\
T8 & 8 & 4,65 \\
T9 & 12 & 6,97 \\
T10 & 13 & 7,55 \\
T11 & 8,72 \\
T12 & 15 & 7,55 \\
L1 & 13 & 6,39 \\
L2 & 11 & 6,39 \\
L3 & 6,39 \\
L4 & 8,13 \\
L5 & 11 & 2,90 \\
S2 & 11 & 0,58 \\
\hline
\end{tabular}

Lokasi lesi terbanyak pada pasien didapatkan pada torakal 20 orang $(40,0 \%)$ dan paling sedikit pada servikal sebanyak 1 orang $(2,0 \%)$. 
Tabel 5. Karakteristik Berdasarkan Abses Paravertebral, Degenerasi Diskus dan Fraktur Kompresi.

\begin{tabular}{lcc}
\hline Variabel & N (75) & \% \\
\hline Abses Paravertebral $(\mathbf{n = 5 0})$ & & \\
Ya & 40 & 80 \\
Tidak & 10 & 20 \\
Degenerasi Diskus $(\mathbf{n = 5 0 )}$ & & \\
Ya & 6 & 12 \\
Tidak & 44 & 88 \\
Fraktur Kompresi $(\mathbf{n = 5 0})$ & 6 & 12 \\
Ya & 44 & 88 \\
Tidak & & \\
\hline
\end{tabular}

Pasien dengan abses paravertebral didapatkan sebanyak 40 orang $(80,0 \%)$, diikuti dengan pasien dengan non abses paravertebral sebanyak 10 orang $(20,0 \%)$. Pasien nondegenerasi diskus didapatkan sebanyak 44 pasien $(88,0 \%)$, lalu sebanyak 6 pasien $(12,0 \%)$ dengan degenerasi diskus.

Sebanyak 44 orang $(88,0 \%)$ pasien menderta fraktur non-kompresi, diikuti pasien dengan fraktur kompresi sebanyak 6 orang $(12,0 \%)$. Hal ini berbeda dari penelitian Wardoyoet al. ${ }^{4}$ yang mendapatkan hasil kasus spondilitis TB di Nusa Tenggara Barat memiliki penyakit penyerta dengan kasus tertinggi fraktur kompresi vertebra sebanyak $8(42.1 \%)$.

\section{Diskusi}

Pada penelitian ini, penderita berjenis kelamin laki-laki lebih berisiko walau dilihat dari persentase tidak terlalu berbeda antara penderita laki-laki maupun perempuan. Hasil ini didukung oleh penelitian Wardoyo, et al., ${ }^{4}$ pada tahun 2012 bahwa jenis kelamin laki-laki lebih banyak terkena spondilitis TB dengan nilai persentase yang juga tidak jauh berbeda. Kelompok umur 15 - 24 tahun merupakan kelompok penderita spondilitis TB, dikarenakan kelompok umur tersebut merupakan kelompok umur yang aktif, memiliki pengetahuan tentang kesehatan yang masih minim serta gaya hidup yang lebih berisiko. Hasil ini sesuai dengan jurnal Garg \& Somvanshi ${ }^{1}$ yaitu prevalensi spondilitis tuberkulosis pada anak-anak sampai dewasa muda. Namun pada penelitian di Iran pada tahun 2010, umur lanjut justru menjadi salah satu risiko terjadinya spondilitis TB. ${ }^{5}$

Status gizi juga berperan terhadap berat ringannya penyakit spondilitis TB, seperti dilaporkan oleh Lai et al. ${ }^{6}$ bahwa individu yang memiliki IMT rendah berpontensi mengalami mortalitas dan morbiditas yang lebih tinggi, hal ini selain dapat memperburuk keadaan umum pasien juga penyulit saat tindakan yang invasif seperti operasi dan proses penyembuhan pasien. ${ }^{7}$ Status gizi yang rendah selain disebabkan oleh patofisiologis penyakit ini juga akibat keadaan sosio-ekonomi yang umumnya di alami oelh penderita spondilitis TB, tetapi pada penelitian ini, gambaran sosio-ekonomi yang rendah tidak tampak jelas, hanya $16 \%$ pasien yang tidak memiliki pekerjaan tetap, sisanya memiliki pekerjaan dan beberapa diantara berstatus sebagai pegawai negeri, anggota kepolisian dan tentara serta pegawai Badan Usaha Milik Negara namun tidak diketahui pendapatan tetap yang didapatkan sehingga sulit menentukan kecukupan ekonomi masing-masing penderita.

Walau riwayat kebiasaan merokok dan konsumsi alkohol juga disebutkan sebagai salah satu faktor risiko, tetapi pada penelitian ini lebih banyak penderita yang mengaku tidak merokok dan mengonsumi alkohol. Penelitian tidak jauh berbeda dengan penelitian Soetioso $^{8}$ dan 
Shetty et al $^{9}$ yang menunjukkan tidak didapatkan hubungan yang signifikan antara kebiasaan merokok dan konsumsi alkohol dengan faktor risiko penyakit TB.

Diagnosis spondilitis TB berdasarkan riwayat konsumsi OAT saat anamnesis cukup sulit karena tidak semua pasien memiliki riwayat minum OAT sebelumnya, begitu pula dengan pemeriksaan laboratorium berdasarkan pemeriksaan BTA, selain memerlukan keahlian pemeriksa untuk menemukan $M$. tuberculosis, juga fokus penyakit saat berobat adalah kelainan akibat $M$. tuberculosis pada tulang belakang. ${ }^{4}$ Pemeriksaan yang paling sensitif untuk penyakit ini menurut Agrawal et al. ${ }^{10}$ dan PCR juga dapat digunakan karena lebih sensitif dibandingkan dengan pemeriksaan BTA. ${ }^{11}$

Lokasi lesi spondilitis TB pada penelitian in paling banyak didapatkan di daerah torakal sebanyak $60 \%$. Pada penelitian $\mathrm{Li}$ et al. ${ }^{12}$ juga menyebutkan bahwa $60 \%$ dari 20 kasus spondilitis tuberculosis, lesi terletak di torakal. Hal ini disebabkan karena posisi torakal yang lebih mudah mengalami penyebaran dari lesi primer di paru dan lebih banyak pasien yang datang berobat dengan keluhan lokal seperti gibbus dan abses paravertebral dibandingkan dengan keluhan sistemik. ${ }^{10,13}$

\section{Kesimpulan}

Berdasarkan hasil penelitian yang telah dilakukan maka dapat disimpulkan bahwa persentase penderita spondilitis TB paling tinggi pada laki laki, kelompok usia 15-24 tahun, status gizi lebih banyak penderita dengan IMT normal dan kurus. Riwayat merokok dan alkohol tidak selalu berhubungan dengan penyakit TB terutama spondilitis TB. Pemeriksaan MRI dan PCR lebih sensitif dibandingkan dengan pemeriksaan BTA sehingga perlu dicarikan jalan keluar agar penderita yang belum terdiagnosis spondilitis TB mendapatkan pemeriksaan yang sensitif dengan biaya yang efektif.

\section{Daftar Pustaka}

1. Garg RK, Somvanshi DS. Spinal tuberculosis: a review. J spinal cord med. 2011 Sep 1;34(5):440-54.

2. Gautam MP, Karki P, Rijal S, Singh R. Pott's spine and Pott's paraplegia. J Nep Med Assoc 2005;44(159):106-15.

3. Faried A, Hidayat I, Yudoyono F, Hanafi R. Spondylitis tuberculosis in neurosurgery department Bandung Indonesia. JSM Neurosurg Spine. 2015;3(3):1059.

4. Wardoyo EH, Cenderadewi M, Rahman H, Putri NA, Purnaning D. Karakteristik spondilitis tuberculosis di Rsup NTB Januari-Desember 2012. Indones J Infect Dis. 2017 Nov 5;2(2):20-3.

5. Alavi SM, Sharifi M. Tuberculous spondylitis: risk factors andclinical/paraclinical aspects in the south west of Iran. J Infect Public Health 2010;3(4):196-200

6. Lai HH, Lai YJ, Yen YF. Association of body mass index with timing of death during tuberculosis treatment. PLoS One. 2017;12(1):e0170104.

7. Yudoyono F, Dahlan RH, Arifin MZ, Adam A. Presurgical aspects of nutrition in tuberculous spondylitis patients. J Med Health. 2018;2(1):596-600

8. Soetioso VB: Hubungan antara merokok dengan kejadian tuberkulosis paru di RSUD Dr. Soewandhie Surabaya. Surabaya: Widya Mandala Catholic University Surabaya, 2014. Disertasi

9. Shetty N, Shemko M, Vaz M, D'souza G. An epidemiological evaluation of risk factors for tuberculosis in South India: a matched case control study. Int J Tuberc Lung Dis. 2006 Jan 1;10(1):80-6.

10. Agrawal V, Patgaonkar PR, Nagariya SP. Tuberculosis of spine. J Craniovertebr Junction Spine. 2010 Jul;1(2):74.

11. Kusmiati T, Narendrani HP. POTT’S Disease. Jurnal Respirasi. 2016;2(3):99-109.

12. Li, T., Liu, T., Jiang, Z., Cui, X. and Sun, J., 2016. Diagnosing pyogenic, brucella and tuberculous spondylitis using histopathology and MRI: A retrospective study. Exp ther med, 12(4),:2069-77.

13. Sukamto AR, Airlangga PA, Yuliawati TH. Karakteristik Pasien Tuberkulosis Tulang Belakang di RSUD Dr. Soetomo Surabaya. Majalah Biomorfologi. 2019 Nov 15;29(1):1-6 